\title{
PENGARUH MOTIVASI \\ TERHADAP PRESTASI DAN \\ KINERJA KARYAWAN \\ PERUSAHAAN ABC
}

\section{Rizka Lailatul Fitriya, Amsal Masitha, Nazmah Zahiroh}

\author{
Universitas Nahdlatul Ulama Sidoarjo \\ Email: \\ rizkalailatul6@gmail.com \\ titamasitha@gmail.com \\ nazmahzahiroh@gmail.com
}

\section{Pengantar}

Kinerja karyawan menjadi hal yang sangat berpengaruh dalam dunia kerja, merekalah yang banyak berperan dalam memproduksi barang dari perusahaan tersebut. Dari barang yang dihasilkan, konsumen dapat mempengaruhi minat konsumen dalam memilih produk (Asitah et al., 2018). Hubungan saling membangun organisasi dengan karyawan serta tanggung jawab dalam menghasilkan produk merupakan manajemen sumber daya manusia (Purnomo, Putri, \& Rosyidah, 2017). 
Kondisi persaingan usaha berjalan sekarang menuntut perusahaan untuk dapat mempertahankan eksistensi, salah satunya melalui peningkatan kinerja karyawan. Menurut Wirawan (2009:5), kinerja adalah cara yang ditunjukkan oleh karyawan untuk melakukan pekerjaan yang telah diberikan oleh atasan dengan sebaik mungkin agar memperoleh hasil yang maksimal sesuai dengan yang diharapkan.

Pekerjaan yang dianggap terlalu berat akan menjadikan karyawan mudah stress dan susah dalam mencari ide baru yang akan dituangkan. Tuntutan kerja yang tinggi yang diberikan perusahaan kepada karyawan akan memicu timbulnya stres pada karyawan yang pada akhirnya akan memengaruhi kinerjanya (Sanjaya, 2012).

$$
\text { Kinerja karyawan yang dipengaruhi }
$$

oleh stres kerja karyawan dan motivasi intrinsik berkaitan dengan pengalaman kerja karyawan, karena dengan pengalaman kerja, maka tugas yang dibebankan dapat dikerjakan dengan baik dan karena pengalaman kerja sangat mempengaruhi kinerja karyawan, dengan mempunyai pengalaman kerja, maka prestasi kerja dan kinerja pun akan meningkat.

Senantiasa harus selalu berpegang teguh pada sifat yang dimiliki oleh Rasul yaitu 
jujur, amanah, fathana, siddiq selain itu juga harus bermodal ikhas, karena Allah ingin agamanya itu di amalkan, poin yang kedua yaitu do'a para alim dan ulama terdahulu lah yang sangat penting dan point yang ke tiga yaitu transparan kepada semua orang agar sesuatu yang di kerjakan mendapat kepercayaan dari orang lain.

Menurut Rofi (2012), perlu diadakannya seleksi dalam penerimaan karyawan, diutamakan yang memiliki banyak pengalaman dalam hal yang bersangkutan dengan perusahaan. agar disaat karyawan tersebut melakukan dan telah diberikan suatu pekerjaan sedikit banyak sudah menguasai bidang yang telah diberikan oleh atasan. Menurut Octaviano (2010:22) pengalaman kerja adalah proses pembelajaran dan pertumbuhan potensi bertingkah laku baik dari jenjang pendidikan formal maupun non formal, dalam arti pengalaman kerja bisa diartikan suatu proses dimana membawa seseorang kepada tingkah pola yang lebih baik.

Motivasi atau motivation berarti pemberian motif, penimbulan motif atau hal yang menimbulkan dorongan atau keadaan yang menimbulkan dorongan. Motivasi dapat pula diartikan faktor yang mendorong or a ng untuk bertindak dengan cara tertentu 
(Manullang, 2008:165). Pemberian motivasi sangat diperlukan bagi semua orang karena berdampak pada peningkatan rasa percaya diri terhadap seseorang. dengan diberikannya motivasi dapat menjadikan dukungan positif dan seseorang dapat terdorong untuk melakukan sesuatu dengan giat (Munjidah, et al., 2017).

Sedangkan motivasi yang bersifat negative adalah sebuah dukungan yang malah akan menjatuhkan rasa percaya diri seseorang yang menjadikan orang tersebut akan merasakan pesimis atau cepat putus asa sebelum menyelesaikan pekerjaannya.

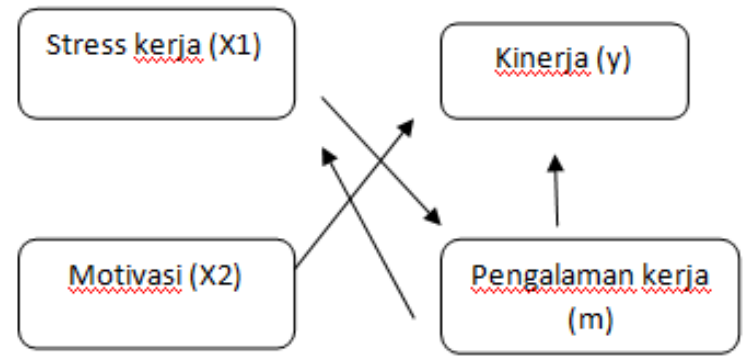

Gambar 1. Model Konseptual Penelitian Sumber : berbagai pendapat dan publikasi dikembangkan untuk penelitian.

\section{Pengaruh motivasi terhadap karyawan}

Karyawan lebih semangat dalam melakukan pekerjaan dan banyak memberikan 
ide - ide kreatif untuk perkembangan perusahaan. Motivasi adalah hal yang dilakukan untuk mempengaruhi semangat dan kedisiplinan seseorang dalam melakukan suatu tugas. Motivasi dianggap sangat penting dalam hal pengaruh kualitas kerja seseorang karena kesuksesan seseorang juga dapat dilihat dari pemberian motivasi terhadap setiap kegiatannya yang menjadikan orang lebih merasa percaya diri dalam melakukan setiap kegiatan. Motivasi bisa menambah rasa percaya diri seseorang dalam melakukan suatu hal. setiap kesempatan yang ada. pada perusahaan yang memiliki pekerjaan cukup berat untuk para karyawannya. Motivasi dapat diberlakukan bagi seluruh karyawan perusahaan $\mathrm{ABC}$.

Motivasi dilakukan oleh pemimpin perusahaan kepada karyawan ataupun karyawan terhadap karyawan dengan berbagai cara seperti pemberian apresiasi penghargaan dan kunjungan wisata. Apresiasi, penghargaan dapat diberikan kepada karyawan yang berprestasi dan memiliki dampak yang besar dalam peningkatan perusahaan. Perlu persiapan budget yang lumayan besar untuk mengajak para karyawan melakukan kunjungan atau wisata agar tidak terlalu stress dengan 
melakukan pekerjaan terus menerus tanpa ada istirahat.

Karena dengan melakukan wisata, karyawan akan fresh kembali fikirannya yang berdampak pada pemikiran mereka terhadap ide - ide yang inovatif untuk perkembangan perusahaan. Menurut Winardi (2007), motivasi pegawai adalah bersedia untuk melakukan usaha tinggi dalam mencapai tujuan organisasi, dapat dijalankan oleh kemampuan dan usaha untuk memenuhi kebutuhan individu tertentu.

Stres kerja dikonseptualisasi dari beberapa titik pandang yaitu definisi stimulus, definisi tanggapan, dan stres sebagai stimulus respons menurut Gibson (1995:203-204). Karyawan yang merasa stress dengan pekerjaannya akan menjadikan karyawan tersebut malas dan mudah merasa pesimis atau putus asa, dimana hal tersebut akan memberikan dampak yang negative terhadap perusahaan. maka dari itu perlu dilakukannya stimulus atau dukungan terhadap para karyawan dengan memberikan motivasi, dimana motivasi yang akan diberikan diharapkan memberikan dampak positif terhadap kinerja karyawan dan karyawan juga memberikan respon yang baik terhadap perlakuan atasannya atau teman sekantor.

Ada 5 kategori penyebab stres kerja 
antara lain keterlibatan pada pekerjaan (intrinsic to job), peran dalam organisasi (role in organization), penghargaan (rewards), hubungan supervisor di tempat kerja (supervisory relationship at work), iklim dan struktur organisasi (organizational structure and climate) menurut Finney (2013).

Hal-hal tersebut merupakan beberapa factor yang dapat menyebabkan stress. Diantaranya ada penghargaan, contohnya penghargaan yang cukup besar yang diberikan oleh atasan terhadap karyawan yang berprestasi, dimana hal tersebut dapat memberikan efek seperti karyawan yang lain akan menjadi iri dan saling berusaha agar mendapatkan seperti yang telah didapatkan oleh rekan kerjanya dengan berfikir keras untuk mengerjakan tugas secara maksimal agar memperoleh reward dari atasan.

Motivasi adalah dorongan dalam diri menyebabkan orang tersebut bertindak. Orang biasanya bertindak karena satu alasan yaitu untuk mencapai tujuan. Jadi, motivasi yaitu pemberian dukungan yang telah diatur dan memiliki tujuan menurut Mathins (2006:114). Seseorang dapat melakukan sesuatu dengan semangat dan sesuai dengan target jika ada dorongan dari orang-orang disekitamya ataupun orang terdekatnya yang sering disebut dengan pemberian motivasi. Motivasi bisa dilakukan tidak hanya dengan 
dukungan berupa uang saja, melainkan dukungan pemberian semangat dan dorongan untuk maju akan lebih memberikan dampak yang baik untuk seseorang yang sedang merasakan tidak percaya diri terhadap pekerjaannya.

Prestasi kerja merupakan hasil kerja baik kuantitas maupun kualitas yang dimana harus didapatkan seorang karyawan untuk menyelesaikan tugasnya sesuai dengan tanggung jawab yang diembannya menurut Mangkunegara (2005). Prestasi kerja dapat dilihat melalui hasil pekerjaan yang dilakukan oleh karyawan, apakah pekerjaan karyawan tersebut selesai dengan waktu yang tepat dan menghasilkan pekerjaan yang baik dan rapi sesuai yang telah diperintahkan.

Prestasi kerja tidak akan dimiliki oleh semua karyawan jika atasan hanya pasrah akan apa yang mereka kerjakan, tetapi atasan juga harus selalu mengontrol pekerjaan karyawan dengan baik dan memberikan motivasi terhadap karyawan agar pekerjaan karyawan tersebut dapat selesai sesuai dengan yang diinginkan. Terciptanya nilai prestasi kerja yang baik bisa tergantung pada persiapan yang sudah matang Menurut 
Siagian (2007).

\section{Penutup}

Motivasi pemberian dukungan seseorang terhadap orang yang memiliki rasa kurang percaya diri dalam melakukan sesuatu. Seseorang akan mudah mengalami stress jika terbeban oleh suatu tuntutan atau tugas yang sangat berat untuk dijalankan. Maka dari itu agar dapat menjadi atasan yang baik dan memiliki karyawan yang semangat, kreatif, inovatif dan pekerja keras, harus memiliki strategi seperti pemberian motivasi untuk semua karyawan.

Motivasi tidak hanya berupa uang saja yang diperuntukkan untuk karyawan sebagai apresiasi, tetapi juga bisa dengan cara meberikan dorongan atau dukungan dalam artian atasan tersebut berkomunikasi langsung dengan karyawan. Bisa juga dengan pemberian stimulus kepada karyawan seperti pemberian penghargaan untuk karyawan yang menunjukkan prestasi kerja. Maka karyawan juga pasti memberikan respon yang baik terhadap apa yang diterapkan oleh atasan tersebut dengan embel-embel penghargaan atau apresiasi.

Hasil hubungan motivasi dengan prestasi kerja yaitu jika semakin banyak 
lembur yang dilakukan karyawan akan mempengaruhi prestasi kerja yang dihasilkan. Prestasi kerja tersebut dapat dijadikan motivasi karyawan untuk selalu menyelesaikan pekerjaan atau target sesuai ketentuan yang telah ditetapkan perusahaan. Yang merupakan upaya dalam peningkatan motivasi karyawan, untuk bagian sumber daya manusia seharusnya mengadakan pelatihan atau seminar motivasi dengan cara brain refreshment, yaitu untuk karyawan dalam hal menyegarkan otak, pemikiran dan fisik karyawan setelah menghabiskan banyak waktu untuk menjalankan rutinitas pekerjaan, menghilangkan rasa bosan dalam menjalankan tugas.

Menumbuhkan kecintaan pada pekerjaan, character building, yaitu mengembangkan sikap dan kebiasaan berpikir positif, memahami dan mengaktifkan potensi diri, meningkatkan keyakinan, motivasi dan percaya diri. Manfaat yang diperoleh dari pelatihan atau seminar adalah untuk peningkatan kuantitas dan kualitas poduktivitas, membentuk sikap, loyalitas dan kerja sama yang lebih menguntungkan.

\section{References}


Asitah, N., Maula, I., Munjidah, A., Nahdiyah, K., Yuniarti, D., Sholichah, S. A., Purnomo, A., Rosyidah, E., Anam, F., Achmadi, A.K., Fahmi, M. (2018, May 25). Urgensi Aktualisasi Manajemen Sumber Daya Manusia untuk Resurgensi Perekonomian di Sidoarjo.

http://doi.org/10.17605/OSF.IO/TG79P Ifo, P., Wisastra, Y., Sagala, E. J., \& Serikat, A. (2016). Pengaruh Pelatihan Terhadap Kompetensi Karyawan Pt . Len Industri ( Persero ) Bandung. Jurnal Manajemen, Strategi Bisnis Dan Kewirausahaan, 10(2), 98-109. Retrieved from http://id.portalgaruda.org/article.php?articl $\mathrm{e}=457766 \& \mathrm{val}=954$

Munjidah, A, Zannah, I.P.N., Purnomo, A., Rosyidah, E. (2017). MI Thoriqussalam Berpegang Kepada Rosul. In Wirausaha Pendidikan Indonesia (Jilid 4). Sidoarjo: Unusida Press.

Purnomo, A., Putri, R. A., \& Rosyidah, E. (2017). Kamus Manajemen Sumber Daya Manusia. Sidoarjo: Unusida Press.

Putu, N., Haryanti, P., \& Ardana, I. K. (2014). Analisis Pengaruh Stres Kerja Dan Motivasi Intrinsik Terhadap Kinerja Karyawan Dengan Pengalaman Kerja Sebagai Variabel Pemoderasi, 8(2), 156165. 
Widyasari, M. (2016). Hubungan Sikap

Karyawan dengan Motivasi Kerja dan

Prestasi Kerja. Jurnal Manajemen,

Strategi Bisnis, Dan Kewirausahaan, 7(1), 57-65. 